Arq. Bras. Med. Vet. Zootec., v.69, n.4, p.785-792, 2017

\title{
Early and late analysis of postpartum stress in newborn foals
}

\author{
[Análise do estresse no pós-parto imediato e tardio em potros neonatos] \\ R.K.S. Cruz ${ }^{1}$, A. Alfonso ${ }^{1}$, M.L.G. Lourenço ${ }^{1 *}$, F.F. Souza ${ }^{1}$, E. Oba ${ }^{1}$, \\ P.R.R. Ramos ${ }^{2}$, S.B. Chiacchio ${ }^{1}$ \\ ${ }^{1}$ Faculdade de Medicina Veterinária e Zootecnia - UNESP - Botucatu, SP \\ ${ }^{2}$ Instituto de Biociências - UNESP - Botucatu, SP
}

\begin{abstract}
The aim of this study was to evaluate newborn foals stress in the first 48 hours of life. Heart rate (HR), heart rate variability (HRV) and serum cortisol concentrations, blood glucose, and lactate were determined in foals $(n=20$, Paint Horse). Cortisol concentrations decreased significantly between four and 48 hours, with the highest concentration at 4 hours after birth. Positive correlations between cortisol and lactate occurred between 12 and 16 hours. And there was a negative correlation between cortisol and lactate 4 hours after birth. Among the values obtained for HR, there was significantly difference between the the value obtained at twelve hours of life moment and all the other moments measured, the highest values were at birth, 24 and 48 hours of life. Among HRV indexes, there were no statistical differences between the variables analysed. The cortisol, HR and HRV alterations were consistent to neonatal stress, but might be related to extrauterine environment adaptation associated to sympathoadrenal response, since those foals were healthy.
\end{abstract}

Keywords: equine neonate, cortisol, heart rate, heart rate variability

\section{RESUMO}

O objetivo deste estudo foi avaliar o estresse em potros neonatos nas primeiras 48 horas de vida. FC, VFC, concentrações de cortisol sérico, glicemia e lactatemia foram determinadas em potros $(n=20$; Paint Horse). As concentrações de cortisol reduziram significativamente, entre quatro e 48 horas, sendo o maior valor observado às quatro horas após o nascimento. Correlações positivas entre cortisol $e$ lactato ocorreram entre 12 e 16 horas de vida. E ocorreu correlação negativa entre cortisol e lactato às quatro horas de vida. Os valores de FC divergiram significativamente entre os momentos ao nascimento, quatro, oito, 16, 20, 24, 36 e 48 horas quanto comparados com as 12 horas de vida, sendo os maiores valores ao nascimento, às 24 e às 48 horas. Entre os índices de VFC, não foram observadas diferenças estatísticas para as variáveis analisadas. As alterações encontradas para cortisol, FC e VFC são condizentes com um quadro de estresse neonatal, mas podem estar relacionadas com o período de adaptação à vida extrauterina, associada a uma resposta simpatoadrenal, visto que os potros apresentavam-se saudáveis.

Palavras-chave: neonato equino, cortisol, frequência cardíaca, variabilidade da frequência cardíaca

\section{INTRODUCTION}

The neonatal period is characterized by a phase of physiological and metabolic adaptation, in which the foal needs to attend to the new challenges of extrauterine life (Pirrone et al.,

Recebido em 17 de agosto de 2016

Aceito em 10 de outubro de 2016

* Autor para correspondência (corresponding author)

E-mail: mege@fmvz.unesp.br
2014). Knowledge about physiology, newborn vigor and early intervention, regarding resuscitation, are essentials to reduce neonatal mortality (Lourenço and Machado, 2013).

The adaptive process to extrauterine life dependents on activation of the hypothalamopituitary-adrenal (HPA) axis, mainly mediated 
by cortisol, a potent stimulator of metabolism (Wood, 1999). In mammals, cortisol promotes adaptation to many physiological conditions, including pregnancy, birth, early lactation and maturation of fetal organ systems (Farrand et al., 2006). This hormone also interferes in many metabolic systems such as the glucose use and catabolism of lipids and proteins, and induces changes in heart rate and blood pressure (Yamada et al., 2007).

The induction of labor by the fetus can be considered a response to chronic stress, which causes the elevation of antepartum cortisol. Acute stress can be questioned since the activation of fetal HPA axis is not accompanied by sympathetic and adrenomedullary activity (Nagel et al., 2015). In human neonates (Irestedt et al., 1982) and calf (Aurich et al., 1993), birth has been confirmed to be stimulated by sympathoadrenal activity. Sympathetic activity can be evaluated not only through the concentration of catecholamines, but also through heart rate analysis and HRV (Nagel et al., 2015), but there is no similar information proved in the equine neonate. In addition to these indexes that are used to assess the neonatal stress, Borruto et al. (2006) reported that high lactate concentration in cord blood or scalp and the persistency of lactic acidosis in human neonates have been considered useful indicators of fetal stress during delivery.

The HRV can be calculated through the electrocardiographic tracing based on the measure of individual RR intervals and comparing adjacent $\mathrm{RR}$, its analysis is performed by indexes obtained using non-linear methods and linear methods, such as time and frequency domains (Aubert et al., 2003). In time domain, each normal RR interval (sinus beats) is measured during a determined time interval, then translator indexes of fluctuations in cardiac cycle are calculated based on statistical or geometric methods (Pumprla et al., 2002).

Cortisol and HRV are good indicators for noninvasive assessment of the HPA and ANS activity in response to psychophysiological stress respectively (Pawan et al., 2013). Thus, the aim of this study was to investigate the effects of stress immediately after birth and during the first 48 hours of life on Paint Horse foals through the analysis of serum cortisol, HRV and HR.

\section{MATERIAL AND METHODS}

The present study was performed in a horse farm located in Avaré, São Paulo state, Brazil. Twenty Paint Horse foals bred using the embryo transfer (ET) technique in crossbred recipients $(n=20$, mean age: 5 to 12 years, $450 \mathrm{~kg}$ mean weight), were evaluated. Ultrasound examinations were performed prior to delivery to ensure fetal viability. Endoparasites were controlled through deworming in accordance with the results of fecal exam. The mares were maintained on grazing (Tifton 85 (Cynodon dactylon)), and it was offered daily $4 \mathrm{~kg}$ of commercial horse feed and had free access to fresh water and mineral salt ad libitum.

This study was approved by the Ethics Committee Animal use (CEUA) from School of Veterinary Medicine and Animal Science (FMVZ) of São Paulo State University (UNESP), Botucatu Campus (number 231/2012 CEUA).

The inclusion criteria considered for this study were foaled spontaneously foals, born through natural birth: delivery in lateral recumbency, expulsion within 20 minutes, assisted delivery without requiring obstetric intervention (rupture of fetal membranes or forced extraction), dorsalanterior presentation of the fetus, and spontaneous rupture of the umbilical cord. The mean duration of pregnancy and delivery were also assessed. The newborns remained with their mothers throughout the experimental period.

The criteria for including the newborns was normal maturity according to data reported by Rossdale et al. (1984), normal viability as assessed by an Apgar score $>7 \quad(8.35 \pm 0.99)$ measured within 10 minutes of birth. The behavior of the foal after birth was also assessed. To assess successfully passive immune transfer, a mandatory prerequisite for the neonatal adaptation process, IgG was measured on serum collected from each foal at 48 hours after birth using the ELISA test (MyBioSource $\AA$, San Diego, California, USA).

Blood samples $(5 \mathrm{~mL})$ were collected by jugular venipuncture using $25 \times 8 \mathrm{~mm}$ needles and disposable plastic syringes. Samples were taken at birth and at $4,8,12,16,20,24,36$, and 48 hours of age. 
Blood glucose and lactate concentrations were assessed using portable analyzers and a drop of total blood for each test (Accu-Chek ${ }^{\circledR}$ Advantage, Roche Diagnostics, Brazil, and Accutrend ${ }^{\circledR}$ Plus, Roche, Mannheim, Germany, for blood glucose and lactate concentrations, respectively) (Tennent-Brown et al., 2007; Hollis et al., 2008).

The blood samples used to assess cortisol concentrations were stored in glass tubes without anticoagulant and maintained at room temperature to facilitate clot retraction. The samples were then centrifuged for 5 minutes at $3000 \mathrm{rpm}$ to collect sera, which was stored in 2$\mathrm{mL}$ microcentrifuge tubes on a $-20^{\circ} \mathrm{C}$ freezer. Cortisol measurements were conducted using a commercial radioimmunoassay test (Coat-acount ${ }^{\circledR}$, Diagnostic Products Corporation, Los Angeles, CA, USA) according to the manufacturer's recommendations. The coefficients of inter- and intra-assay variation for the cortisol measurements were $0.62 \%(48.70$ $\mathrm{g} / \mathrm{dL})$ for the upper control and 1.08\% (1.07 $\mathrm{g} / \mathrm{dL}$ ) for the lower control.

An electrocardiogram was performed on the six leads in the frontal plane (I, II, III, aVR, aVL, and aVF) with the ECG Acquisition Module PC$\mathrm{ECG}$, version $2.0^{2}$ over one minute with a speed of $50 \mathrm{~mm} / \mathrm{s}$ and sensitivity set to $1 \mathrm{~cm}=1 \mathrm{mV}$. The foals were monitored during birth and at 4 , $8,12,16,20,24,36$, and 48 hours of age. The recording location had rubber-coated floor plates to avoid interference in the electrocardiographic tracing, and the animals were not sedated, tranquilized or anesthetized.

The electrodes commonly used were "alligator clips" moistened with alcohol, which the positive electrode ("left forelimb," the yellow one) was positioned in the region above the humerus radio-ulnar left joint, the negative electrode ("right hindlimb", the red one) on the right, the third electrode ("right hindlimb", the black one) above the femoro-tibial-patellar right joint and the fourth electrode ("left pelvic limb", the green one), in the same location, however at the left side.

For each electrocardiographic test the following parameters were evaluated: mean HR, length of RR interval and HRV in the frequency domain, through the analysis of consecutive RR intervals (in milliseconds), from which sample variance was calculated (Fig. 1), which natural logarithm (neperian) was representing the vasovagal tonus index (VVTI) (Carareto et al., 2007), the root mean square of differences from the mean interval, overall HRV (RMSM) and square root of the mean squared differences of successive RR intervals (RMSSD) (Siimes et al., 1990). The choice of these indexes was made because they are sensitive indicators and are conventionally accepted to characterize the HRV (Malik, 1996).

$$
\mathrm{VVTI}=\log _{\mathrm{e}}\left(\frac{N \sum_{i=1}^{N} R R_{i}^{2}-\left(\sum_{i=1}^{N} R R_{i}\right)^{2}}{N(N-1)}\right) \mathrm{RMSSD}=\sqrt{\frac{\sum_{i=1}^{N-1}\left(R R_{i}-R R_{1+i}\right)^{2}}{N-1}} \quad \mathrm{RMSM}=\sqrt{\frac{\sum_{i=1}^{N}\left(R R_{i}-\overline{R R}\right)^{2}}{N}}
$$

Figure 1. Rule for calculation of $\operatorname{HRV}(\Sigma=$ sum; RR $=\mathrm{RR}$ intervals; $N=\mathrm{RR}$ intervals numbers in the selected series; $\log _{\mathrm{e}}=$ natural logarithm neperian).

In the statistical analysis of the variables (HRV, HR, blood glucose, lactate, and cortisol concentration), the normality test (KolmogorovSmirnov) was used, followed by variance technical analysis for model repeated measures, ANOVA. The Tukey test was used to adjust the p-values resulted from multiple comparisons. In addition, Pearson's correlation was calculated (PROC CORR in SPSS) between dependent variables among each time point assessed. The data are reported as untransformed least-squares means \pm standard deviations. For all analyses, $\mathrm{p}<0.05$ was considered significant (PROC MIXED, SAS Institute, 2011).

\section{RESULTS}

The mean and standard deviation of the lactate concentrations, cortisol and glucose from 20 neonatal foals were statistically significant and are described in Table 1. There was no significant difference between the blood glucose concentrations at birth $(98.90 \pm 35.97 \mathrm{mg} / \mathrm{dL})$ and 4 hours after birth $(108.05 \pm 26.23 \mathrm{mg} / \mathrm{dL})$, although a significant increase occurred 
between birth and 8 hours after birth $(127.90 \pm 27.15 \mathrm{mg} / \mathrm{dL})$. The blood glucose concentrations stabilized at $148.95 \pm 29.59 \mathrm{mg} / \mathrm{dL}$ after the first 12 hours. Blood lactate concentrations decreased across the time points tested, with the highest value measured at birth $\quad(5.48 \pm 2.17 \mathrm{mmol} / \mathrm{L})$. Significant differences were detected between birth and $24(2.76 \pm 1.31 \mathrm{mmol} / \mathrm{L})$ and 36 hours $(2.51 \pm 0.96 \mathrm{mmol} / \mathrm{L})$ after birth but stabilized after 24 hours $(\mathrm{P}<0.001)$.

Table 1. Mean and standard deviation of biochemical analysis, and cortisol levels in 20 foals at birth and 4, 8, 12, 16, 20, 24, 36 and 48 hours postpartum

\begin{tabular}{llll}
\hline Time & Lactate $(\mathrm{mmol} / \mathrm{L})$ & Cortisol $(\mu \mathrm{g} / \mathrm{dL})$ & Glucose $(\mathrm{mg} / \mathrm{dL})$ \\
\hline Birth & $5.48 \pm 2.17 \mathrm{~d}$ & $9.89 \pm 7.25 \mathrm{~cd}$ & $98.90 \pm 35.97 \mathrm{a}$ \\
$4 \mathrm{~h}$ & $4.58 \pm 1.67 \mathrm{~cd}$ & $10.46 \pm 7.46 \mathrm{~d}$ & $108.05 \pm 6.23 \mathrm{ab}$ \\
$8 \mathrm{~h}$ & $4.26 \pm 1.63 \mathrm{bcd}$ & $6.90 \pm 5.25 \mathrm{abc}$ & $127.90 \pm 27.15 \mathrm{bc}$ \\
$12 \mathrm{~h}$ & $3.82 \pm 1.79 \mathrm{abc}$ & $6.13 \pm 4.57 \mathrm{bcd}$ & $148.95 \pm 29.59 \mathrm{~cd}$ \\
$16 \mathrm{~h}$ & $3.42 \pm 1.78 \mathrm{abc}$ & $5.52 \pm 4.58 \mathrm{abc}$ & $154.10 \pm 29.19 \mathrm{~d}$ \\
$20 \mathrm{~h}$ & $3.07 \pm 1.73 \mathrm{abc}$ & $4.45 \pm 5.01 \mathrm{ab}$ & $160.05 \pm 20.68 \mathrm{~d}$ \\
$24 \mathrm{~h}$ & $2.76 \pm 1.31 \mathrm{ab}$ & $4.97 \pm 4.70 \mathrm{a}$ & $166.55 \pm 18.96 \mathrm{~d}$ \\
$36 \mathrm{~h}$ & $2.51 \pm 0.96 \mathrm{a}$ & $5.47 \pm 4.73 \mathrm{ab}$ & $161.00 \pm 17.17 \mathrm{~d}$ \\
$48 \mathrm{~h}$ & $2.43 \pm 0.87 \mathrm{a}$ & $5.21 \pm 3.35 \mathrm{abc}$ & $155.70 \pm 19.37 \mathrm{~d}$ \\
\hline $\mathrm{p}$ value & $<0.001$ & $<0.01$ & $<0.001$ \\
\hline
\end{tabular}

Different superscripted letters (a,b,c,d) indicate significant differences between time points $(\mathrm{P}<0.05)$.

Cortisol concentrations were highest at birth $(9.89 \pm 7.25 \mu \mathrm{g} / \mathrm{dL})$ and 4 hours after birth $(10.46 \pm 7.46 \mu \mathrm{g} / \mathrm{dL})$. The concentrations then significantly decreased from birth to 20 $(4.45 \pm 5.01 \mu \mathrm{g} / \mathrm{dL}), 24(4.97 \pm 4.70 \mu \mathrm{g} / \mathrm{dL})$, and 36 hours $(5.47 \pm 4.73 \mu \mathrm{g} / \mathrm{dL})$. They were also significant lower between 4 hours and 8 $(6.90 \pm 5.25 \mu \mathrm{g} / \mathrm{dL}), 16(5.52 \pm 4.58 \mu \mathrm{g} / \mathrm{dL}), 20,24$, 36 , and 48 hours $(5.21 \pm 3.35 \mu \mathrm{g} / \mathrm{dL})$. Positive correlations between cortisol and lactate concentrations were presented at 12 and 16 hours postpartum $(\mathrm{r}=0.67, \mathrm{p}=0.001)$ and $(\mathrm{r}=0.58, \mathrm{p}$ $=0.006)$, respectively. The cortisol and lactate concentrations were negatively correlated at 4 hours $(r=-0.47, p=0.03)$. Lactate, glucose and cortisol concentrations during the first 48 hours postpartum are shown in Figure 2.

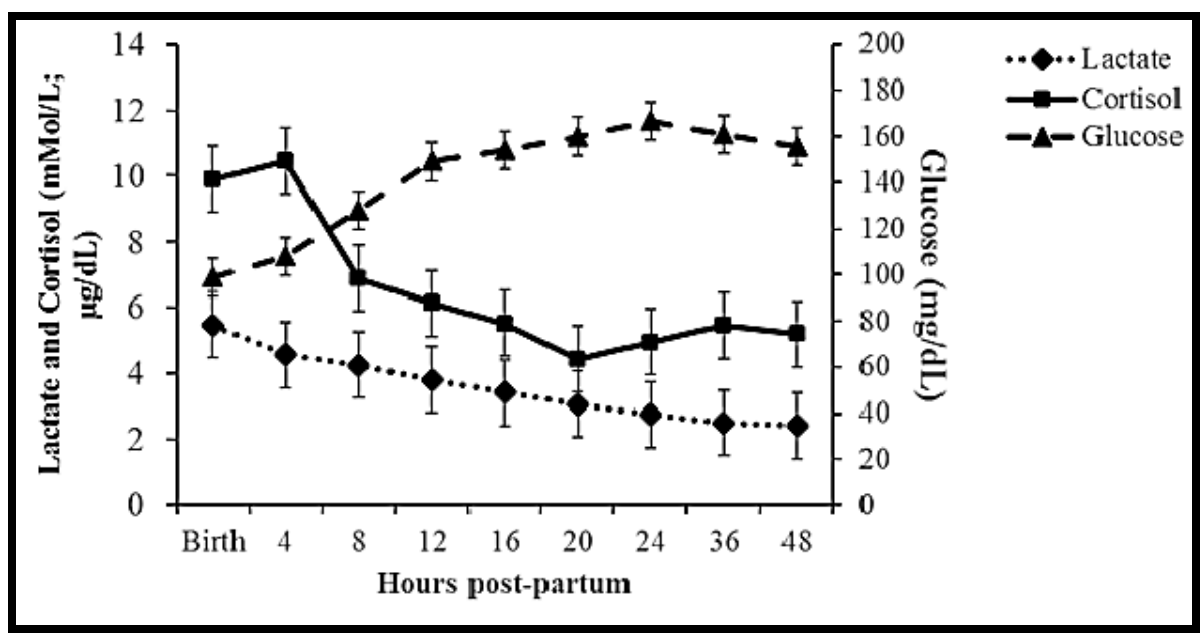

Figure 2. Lactate, glucose and cortisol concentrations in 20 foals at birth and 4, 8, 12, 16, 20, 24, 36 and 48 hours postpartum. Error bars show \pm 1 SEM 
The values of HR and HRV indexes (RMSM; RMSSD and VVTI) are described in Table 2, but statistical differences were found only for HR.

The values found for HR differed statistically on the times at birth, 4, 8, 16, 20,24, 36 and 48 hours, when compared with 12 hours of life. The highest values were recorded at birth, 24 and 48 hours, and the lower at 4 and 36 hours (Figure 3 ). Regarding RR interval, the values increased during the first 20 hours of life, and decreased discreetly at 24 hours and returned to increase at 36 hours (Figure 4A).

Table 2. Mean and standard deviation of heart rate variability indexes in 20 newborns foals from Paint Horse breed during the first 48 hours of life

\begin{tabular}{cllllll}
\hline & Hours & HR $(\mathrm{bpm})$ & RR(ms) & $\begin{array}{l}\text { RMSM } \\
(\mathrm{ms})\end{array}$ & $\begin{array}{l}\text { RMSSD } \\
(\mathrm{ms})\end{array}$ & VVTI (ms) \\
\hline & Birth & $117,1 \pm 14,6 \mathrm{a}$ & $521,6 \pm 68,5$ & $2,10 \pm 2,46$ & $2,98 \pm 4,03$ & $3,96 \pm 0,12$ \\
Hours & 4 hours & $111,6 \pm 14,1 \mathrm{a}$ & $541,3 \pm 73,8$ & $1,51 \pm 1,31$ & $1,99 \pm 1,83$ & $3,99 \pm 0,12$ \\
after & hours & $113,9 \pm 19,1 \mathrm{a}$ & $540,9 \pm 87,5$ & $1,58 \pm 1,61$ & $1,93 \pm 1,76$ & $3,99 \pm 0,14$ \\
delivery & 16 hours & $112,5 \pm 20,2 \mathrm{bc}$ & $545,8 \pm 84,9$ & $1,84 \pm 0,97$ & $2,08 \pm 1,11$ & $4,00 \pm 0,14$ \\
& 20 hours & $113,7 \pm 16,4 \mathrm{a}$ & $539,8 \pm 82,7$ & $1,94 \pm 1,89$ & $1,96 \pm 1,67$ & $3,99 \pm 0,14$ \\
& 24 hours & $113,9 \pm 14,4 \mathrm{ac}$ & $536,3 \pm 70,8$ & $1,72 \pm 1.35$ & $1,77 \pm 1,21$ & $3,98 \pm 0,11$ \\
& 36 hours & $111,7 \pm 19,2 \mathrm{a}$ & $555,7 \pm 80,2$ & $2,04 \pm 1,72$ & $2,65 \pm 2,35$ & $4,01 \pm 0,13$ \\
& 48 hours & $117,1 \pm 14,6 \mathrm{a}$ & $523,0 \pm 89,5$ & $2,29 \pm 2,02$ & $2,80 \pm 2,85$ & $3,96 \pm 0,15$ \\
\hline
\end{tabular}

Different superscripts letters $(\mathrm{a}, \mathrm{b}, \mathrm{c})$ denotes a significant difference; $\mathrm{P}<0.05$. HR, heart rate; RR, beat-to-beat interval; RMSM, the root-mean square differences of successive R-R intervals; RMSSD, the mean of the standard deviations for all R-R intervals; VVTI, vasovagal tonus index.

The vasovagal tonus index (VVTI) values oscillated among the analyzed moments, obtaining similar values at birth and at 48 hours (Figure 4B). The RMSM reduced from birth to 20 hours, increasing again in the following moments, reaching its highest value at 48 hours
(Figure 4C). The RMSSD rates have also reduced in the analyzed time until the 20 hour moment, and increased in the 24 hours of life, but the highest value was registered at birth (Figure 4D).

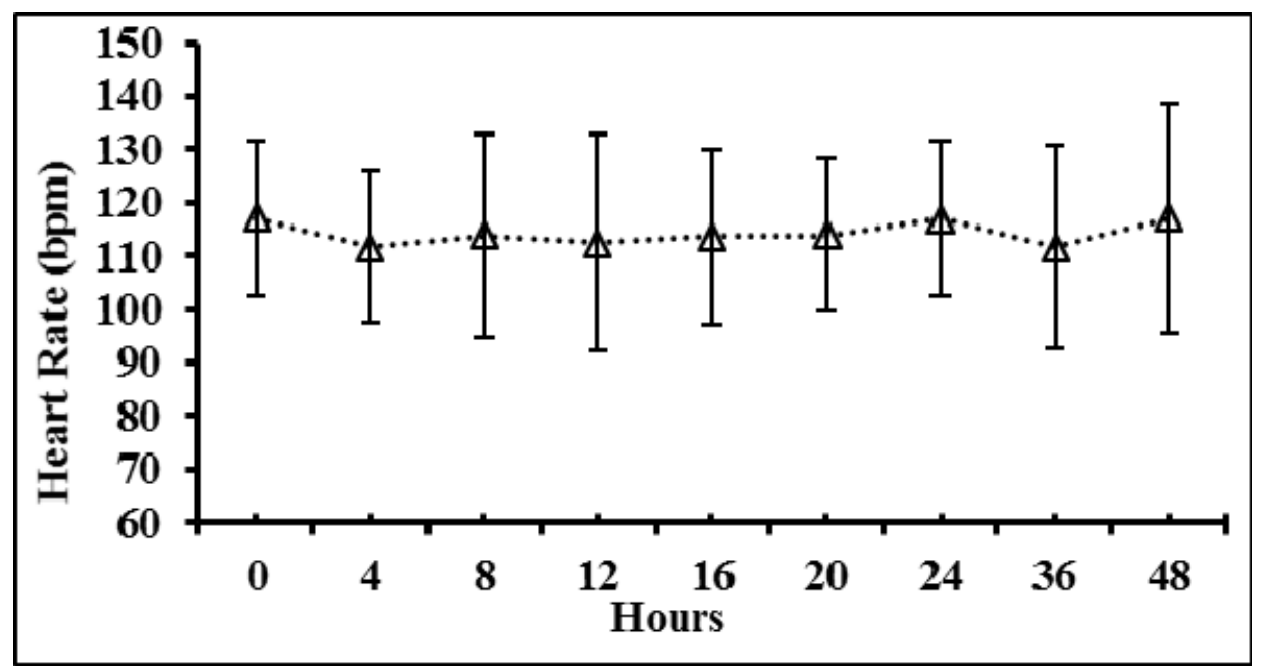

Figure 3. Heart rate from 20 Paint Horse newborn foals $(\Delta)$ in the first 48 hours of life. 

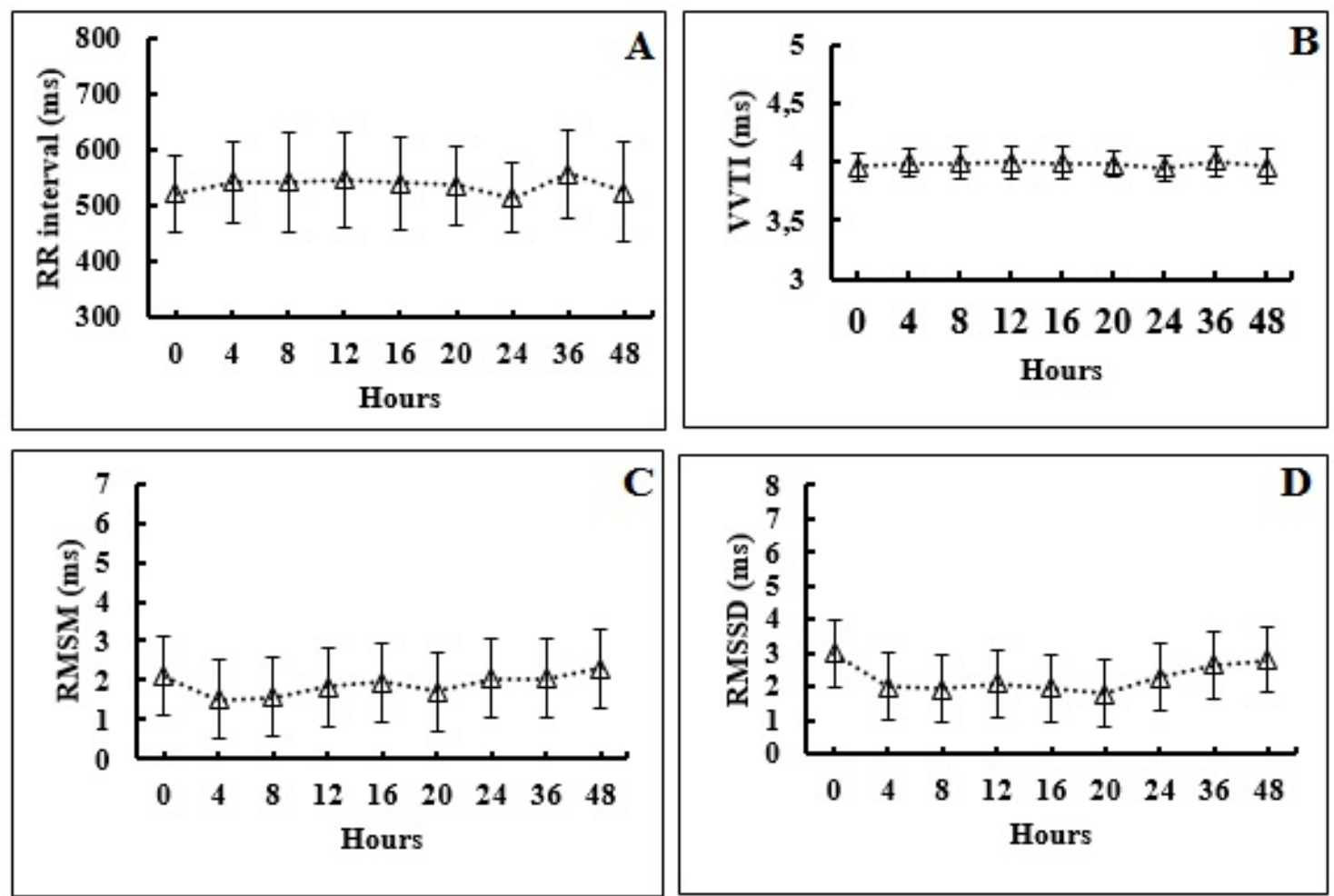

Figure 4. HRV variables: (A) RR interval; (B) the vasovagal tonus index (VVTI); (C) the root-mean square differences of successive R-R intervals (RMSM); and (D) the mean of the standard deviations for all R-R intervals (RMSSD), from 20 Paint Horse newborn foals $(\Delta)$ in the first 48 hours of life.

\section{DISCUSSION}

The blood glucose concentrations measured at birth were lower than Veronesi et al. (2014). This decrease is part of the normal transition to an extrauterine existence through a series of triggers and events that activate endocrine and metabolic responses associated with successful adaptation (Adamkin, 2015). Blood lactate concentrations significantly decreased between birth and 24 hours after birth, similar to the patterns reported by other authors (Axon and Palmer, 2008), most likely because of the gradual clearance and consumption of lactate through pyruvate conversion for energy production, thus reversing tissue hypoxia and favoring the neonatal prognosis (Souza and Elias, 2006). Positive correlations between lactate and cortisol have also been reported by other authors and may be related to the release of catecholamines during the delivery process or even with physiological hypoxia at birth (Fowden et al., 2000). Animal age should thus be considered when analyzing these concentrations, especially during the first 24 hours, these increases being related to the period of neonatal adaptation.

The cortisol concentrations found in the present study differed from the values reported on plasma of full-term foals at birth and at 2 hours of life (Silver et al., 1991) and, in another foal study, at birth (Comin et al., 2012). These differences may be related to the methodology or the different measurement techniques used. Some authors advocate in favor of cortisol determination through salivary analysis (Nagel et al., 2015) to avoid stress caused by repeated blood collections. However, according Negrão et al. (2004), even though cortisol levels in the plasma are higher than in saliva, the two profiles showed similar responses following administration of the same concentrations of ACTH in cattle, and a significant positive correlation between the two samples was observed.

Cortisol concentrations were significantly higher in the first four hours of life, after ingestion of colostrum when the animals were standing. 
Nagel et al. (2012) also found maximum concentrations of cortisol when the foals were standing and after ingestion of colostrum. In calves the opposite is observed, plasma cortisol and the release of catecholamines during delivery can increase and decrease after birth (Aurich et al., 1993). This can be explained by the delivery period that is higher in cattle than in mares. In this specie, fetal hypoxia stimulates the release of catecholamine and cortisol, leading to highest concentrations at birth (Nagel et al., 2015).

The high values of heart rate at birth and cortisol levels at birth and during the first 4 hours of life, can indicate a pronounced stress-like response once the foal was born (Nagel et al., 2015). The ANS is responsible for the immediate response to exposure of stressor factors. Its two branches (sympathetic and parasympathetic) change rapidly the organs physiological states through innervation (Ulrich-Lai and Herman, 2009).

Thus, the sympathetic innervation could had increased rapidly the heart rate of these animals, through the release of adrenal hormones as occurs with cortisol, through sympathetic stimulation of the suprarenal cortex cells (UlrichLai and Herman, 2009). Immediately after birth, the sympathoadrenal activity is markedly elevated in humans (Irestedt et al., 1982) and calves (Aurich et al., 1993), in according with the findings of this study, which indicates a predominance of the sympathetic branch in the first 48 hours of life.

The neonate has low levels of blood pressure, blood volume and peripheral vascular resistance, and in order to maintain an adequate perfusion, it maintains higher frequency and cardiac output as well as the central venous pressure, when compared to adults (Adelman and Wright, 1985). The postnatal maturation of the central circulation control, cardiac output and peripheral vascular system, as well as developmental changes in the sinus node (Blanco et al., 1988) change the HR and HRV. Therefore, at this period of neonate life, it is suggested that the reduced values in HRV indexes are not justified by the lack of neonatal viability, but because of the sympathetic branch predominance which is necessary to biological system demands and maintenance of homeostasis.

\section{CONCLUSIONS}

The high values of heart rate observed at birth and the cortisol at birth and during the first 4 hours of life, can indicate a pronounced stress-like response once the foal was born. The results for HR and HRV suggest that in the first 48 hours after birth, the newborn's ANS is developed but immature related to the balance between the sympathetic and vagal branch, occurring a sympathetic autonomic prevalence. Variations indicated a considerable impact on the cardiovascular system and the adaptation to extrauterine life of the foal is associated with a significant response from sympathoadrenal system.

\section{ACKNOWLEDGEMENTS}

The authors thank the São Paulo Research Foundation (Fundação de Amparo à Pesquisa do Estado de São Paulo, FAPESP) for financial support. And the authors acknowledge the Escaramuça farm for allowing the use of their animals in the present study.

\section{REFERENCES}

ADAMKIN, D.H. Metabolic screening and postnatal glucose homeostasis in the newborn. Pediatr. Clin. $N$. Am., v.62, p.385-409, 2015.

ADELMAN, R.D.; WRIGHT, J. Systolic blood pressure and heart rate in the growing beagle puppy. Dev. Pharmacol. Ther., v.8, p.396-401, 1985.

AUBERT, A.E.; SEPS, B.; BECKERS, F. Heart rate variability in athletes. Sports Med., v.33, p.889-919, 2003.

AURICH, J.E.; DOBRINSKI, I.; PETERSEN, A. et al. Influence of labor and neonatal hypoxia on sympathoadrenal activation and methionineenkephalin release in calves-Influence of labor and neonatal hypoxia on sympathoadrenal activation and methionine enkephalin release in calves. Am. J. Vet. Res., v.54, p.1333-1338, 1993.

AXON, J.E.; PALMER, J.E. Clinical pathology of the foal. Vet. Clin. N. Am. Equine Pract., v.24, p.357-385, 2008.

BLANCO, C.E.; DAWES, G.S.; HANSON, M.A.; MCCOOKE, H.B. Carotid baroreceptors in fetal and newborn sheep. Pediatr. Res., v.24, p.342-346, 1988. 
BORRUTO, F.; COMPARETTO, C.; WEGHER, E.; TREISSER, A. Screening of foetal distress by assessment of umbilical cord lactate. Clin. Exp. Obstet. Gynecol., v.33, p.219-222, 2006.

CARARETO, R.; SOUSA, M.G.; ZACHEU, J.C. et al. Variabilidade da frequência cardíaca em cães anestesiados com infusão contínua de propofol e sufentanil. Arq. Bras. Med. Vet. Zootec., v.59, p.329323, 2007.

COMIN, A.; VERONESI, M.C.; MONTILLO, M. et al. Hair cortisol level as a retrospective marker of hypothalamic-pituitary-adrenal axis activity in horse foals. Vet. J., v.194, p.131-132, 2012.

FARRAND, K.; MCMILLEN, I.C.; TANAKA, S.; SCHWARTZ, J. Subpopulations of corticotrophs in the sheep pituitary during late gestation: effects of development and placental restriction. Endocrinology, v.147, p.4762-4771, 2006

FOWDEN, A.L.; TAYLOR, P.M.; WHITE, K.L.; FORHEAD, A.J. Ontogenic and nutritionally induced changes in fetal metabolism in the horse. J. Physiol., v.528, p.209-219, 2000.

HOLLIS, A.R.; DALLAP-SCHAER, B.L.; BOSTON, R.C.; WILKINS, P.A. Comparison of the Accu-Chek Aviva point-of-care glucometer with blood gas and laboratory methods of analysis of glucose measurement in equine emergency patients. J. Vet. Intern. Med., v.22, p.1189-1195, 2008.

IRESTEDT, L.; LAGERCRANTZ, H.; HJEMDAHL, P. et al. Fetal and maternal plasma catecholamine levels at elective cesarean section under general or epidural anesthesia versus vaginal delivery. Am. J. Obstet. Gynecol., v.142, p.1004-1010, 1982.

LOURENÇO, M.L.G.; MACHADO, L.H.A. Características do período de transição fetal- neonatal e particularidades fisiológicas do neonato canino. Rev. Bras. Reprod. Anim., v.37, p.303-308, 2013.

MALIK, M. Task force - heart rate variability standards of measurement, physiological interpretation and clinical use. Circulation, v.93, p.1043-1065, 1996.

NAGEL, C.; ERBER, R.; BERGMAIER, C. et al. Cortisol and progestin release, heart rate and heart rate variability in the pregnant and postpartum mare, fetus and newborn foal. Theriogenology, v.78, p.759-767, 2012.

NAGEL, C.; ERBER, R.; ILLE, N. et al. Heart rate and salivary cortisol concentrations in foals at birth. Vet. J., v.203, p.250-252, 2015.
NEGRÃO, J.A.; PORCIONATO, M.A.; DE PASSILLÉ, A.M.; RUSHEN, J. Cortisol in saliva and plasma of cattle after ACTH administration and milking. J. Dairy Sci., v.87, p.1713-1718, 2004.

PAWAN, C.; CHWO, S.M.; LI, I. Saliva cortisol and heart rate variability as biomarkers in understanding emotional reaction and regulation of young children: a review. Psychology, v.4, p.19-26, 2013.

PIRRONE, A.; ANTONELLI, C.; MARIELLA, J.; CASTAGNETTI, C. Gross placental morphology and foal serum biochemistry as predictors of foal health. Theriogenology, v.81, p.1293-1299, 2014.

PUMPRLA, J.; HOWORKA, K.; GROVES, D. et al. Functional assessment of heart rate variability: physiological basis and practical applications. Int. J. Cardiol., v.84, p.1-14, 2002.

ROSSDALE, P.D.; OUSEY, J.C.; SILVER, M.; FOWDEN, A. Studies on equine prematurity 6: guidelines for assessment of foal maturity. Equine Vet. J., v.16, p.300-302, 1984.

SAS INSTITUTE INC. SAS/Stat 9.3 user's guide. Cary, N.C., SAS Institute Inc, 2011.

SIIMES, A.S.; VÄLIMÄKI, I.A.; ANTILA, K.J. et al. Regulation of heart rate variation by the autonomic nervous system in neonatal lambs. Pediatr. Res., v.27, p.383-391, 1990.

SILVER, M.; FOWDEN, A.L.; KNOX, J. et al. Relationship between circulating tri-iodothyronine and cortisol in the perinatal period in the foal. J. Reprod. Fertil. Suppl., v.44, p.619-626, 1991.

SOUZA, M.H.L.; ELIAS, D.O. Valor prognóstico da acidose láctica durante a perfusão. Rev. Latinoam. Tecnol. Extra, v.13, p.14-17, 2006.

TENNENT-BROWN, B.S.; WILKINS, P.A.; LINDBORG, S. et al. Assessment of a point of care lactate monitor in emergency admissions of adult horses to a referral hospital. J. Vet. Intern. Med., v.21, p.1090-1098, 2007.

ULRICH-LAI, Y.M.; HERMAN, J. Neural regulation of endocrine and autonomic stress response. Nat. Rev. Neurol., v.10, p.307-409, 2009.

VERONESI, M.C.; GLORIA, A.; PANZANI, S. et al. Blood analysis in newborn donkeys: hematology, biochemistry, and blood gases analysis. Theriogenology, v.82, p.294-303, 2014.

WOOD, C.E. Control of parturition in ruminants. J. Reprod. Fertil., v.54, p.115-126, 1999.

YAMADA, J.; STEVENS, B.; DE SILVA, N. et al. Hair cortisol as a potential biologic marker of chronic stress in hospitalized neonates. Neonatology, v.92, p.42-49, 2007. 